\title{
Identification of Flap Structure-Specific Endonuclease 1 as a Factor Involved in Long-Term Memory Formation of Aversive Learning
}

\author{
Lorena Saavedra-Rodríguez, ${ }^{1,2}$ Adrinel Vázquez, ${ }^{1,2}$ Humberto G. Ortiz-Zuazaga, ${ }^{4}$ Nataliya E. Chorna, ${ }^{3}$ \\ Fernando A. González, ${ }^{3}$ Lissette Andrés, ${ }^{1}$ Karen Rodríguez, ${ }^{1}$ Fernando Ramírez, ${ }^{1}$ Alan Rodríguez, ${ }^{1}$ and \\ Sandra Peña de Ortiz ${ }^{1,2}$ \\ ${ }^{1}$ Molecular and Cellular Cognition Laboratory and ${ }^{2}$ Functional Genomics Research Center, Department of Biology, and ${ }^{3}$ Department of Chemistry, \\ University of Puerto Rico, Río Piedras Campus, San Juan, Puerto Rico 00931-3360, and ${ }^{4}$ High Performance Computing Facility, University of Puerto Rico, \\ Central Administration, San Juan, Puerto Rico 00931
}

We previously proposed that DNA recombination/repair processes play a role in memory formation. Here, we examined the possible role of the $f e n-1$ gene, encoding a flap structure-specific endonuclease, in memory consolidation of conditioned taste aversion (CTA). Quantitative real-time PCR showed that amygdalar fen-1 mRNA induction was associated to the central processing of the illness experience related to CTA and to CTA itself, but not to the central processing resulting from the presentation of a novel flavor. CTA also increased expression of the Fen-1 protein in the amygdala, but not the insular cortex. In addition, double immunofluorescence analyses showed that amygdalar Fen-1 expression is mostly localized within neurons. Importantly, functional studies demonstrated that amygdalar antisense knockdown of fen-1 expression impaired consolidation, but not short-term memory, of CTA. Overall, these studies define the fen-1 endonuclease as a new DNA recombination/repair factor involved in the formation of long-term memories.

\section{Introduction}

Conditioned taste aversion (CTA) represents a form of conditioning established when animals associate a new taste [conditioned stimulus (CS)] with visceral illness [unconditioned stimulus (US)], resulting in the subsequent avoidance of such taste (Garcia et al., 1985; Bernstein, 1999). Acquisition of taste aversion results from and requires the succession of different phases within the brain: encoding and storing the novel taste, processing the somatic illness, and finally establishing an association between the taste memory and the illness experience (Bures, 1998). The aversive memories generated during CTA are robust and persistent in time, and involve brain regions such as the amygdala and the insular cortex (Gallo et al., 1992; Bermúdez-Rattoni and Yamamoto, 1998; Lamprecht and Dudai, 2000). Moreover, the taste (Bermúdez-Rattoni, 2004; Yamamoto, 2006) and illness (Lamprecht and Dudai, 1996; Yamamoto et al., 1997; Spencer and Houpt, 2001; Bernstein and Koh, 2007; St Andre et al., 2007) components of CTA induce specific neuromolecular processes in

\footnotetext{
Received Aug. 24, 2008; revised March 11, 2009; accepted March 24, 2009.

This work was supported by National Institutes of Health (NIH)-National Center for Research Resources Grants 5P20 RR-15565-02 and P20 RR-016470, NIH-National Institute of General Medical Sciences Grant S06GM08102, and NIH-National Institute of Mental Health Grant 1SC1MH086072-01. The following predoctoral fellowships supported L.S.-R.: Merit Fellowship and Dissertation Fellowship from the Deanship of Graduate Studies, University of Puerto Rico at Río Piedras. Finally, L.A. and A.R. are undergraduate research trainees supported by NIH Grant 5T34GM07821. We also acknowledge the Materials Characterization Center at the University of Puerto Rico for administrative support.

Correspondence should be addressed to Dr. Sandra Peña de Ortiz, Department of Biology, University of Puerto Rico, P.0. Box 23360, San Juan, PR 00931-3360. E-mail: sandra@hpcf.upr.edu.

DOI:10.1523/JNEUROSCI.4033-08.2009

Copyright $\odot 2009$ Society for Neuroscience $\quad$ 0270-6474/09/295726-12\$15.00/0
}

the brain. For example, the amygdala shows robust neural activation to either the new taste or the toxin-induced illness experience when they are presented separately (Bernstein and Koh, 2007). The individual presentation of the CS or US seems to elicit the activation of amygdalar cellular and molecular signals, which could be required for the final establishment of the association of both experiences. Here, we embarked in a study aimed at deciphering molecular mechanisms involved in CTA consolidation, including those related to the representation of taste and illness individually, with a specific interest in identifying factors related to DNA recombination/repair processes.

Previously, we reported that DNA ligase-dependent recombination/repair processes are necessary for consolidation of CTA (Wang et al., 2003) and context fear conditioning (ColónCesario et al., 2006a). We also showed that the mature rodent brain displays DNA ligase-dependent nonhomologous end joining (NHEJ) (Ren and Peña de Ortiz, 2002), a known DNA recombination/repair mechanism required for the final stages of sitespecific recombination in the immune system (Soulas-Sprauel et al., 2007). Importantly, we found that NHEJ is rapidly induced in the hippocampus after contextual fear conditioning (ColónCesario et al., 2006a). Additional studies by us determined that the gene encoding terminal deoxynucleotidyl transferase (TdT), known to be involved in somatic recombination in the immune system (Benedict et al., 2000), is also associated to learning and memory processes in the mouse brain (Peña de Ortiz et al., 2003). The experiments presented here resulted in the discovery that the gene encoding flap structure-specific DNA endonuclease-1 (Fen1), identified by us using DNA microarrays (our unpublished 
observations), is a factor necessary for consolidation of CTA. The fact that an endonuclease, such as Fen-1, is required for longterm memory (LTM) formation of aversive experiences supports the notion that DNA recombination/repair pathways are involved in processes that lead to the storage of information in the brain.

\section{Materials and Methods}

Animals. Male Long-Evans rats (Harlan) weighing 275-300 g were used. They were individually caged at $\pm 22^{\circ} \mathrm{C}$ in a $12 \mathrm{~h}$ light/dark cycle, with food and water ad libitum, except during behavioral tests during which water restriction was used at certain points (see below). All procedures were approved by the Institutional Animal Care and Use Committee of the Río Piedras Campus at the University of Puerto Rico in compliance with the National Institutes of Health (NIH) Guidelines for the Care and Use of Laboratory Animals (Department of Health and Human ServicesNIH publication no. 86-23).

Behavioral training. The CTA training was done as previously described by us (Ge et al., 2003; Wang et al., 2003). Briefly, rats were habituated for $4 \mathrm{~d}$ to drink plain water during $10 \mathrm{~min}$ each day, using the bottle presentation method. On day 5, CTA-trained animals were exposed to the novel flavor or CS $(0.1 \%$ dextrose solution $)$ in the drinking bottle for $10 \mathrm{~min}$. This was followed $40 \mathrm{~min}$ later by an intraperitoneal $\mathrm{LiCl}$ injection (100 mg/kg body weight), used as the US in our studies. To examine fen-1 molecular changes related to novel taste or illness experiences, we used the following additional behavioral groups: flavor-only animals, exposed to the CS and $40 \mathrm{~min}$ later injected (intraperitoneally) with saline solution, and toxin-only animals, exposed to plain water instead of $\mathrm{CS}$ and 40 min later injected (intraperitoneally) with $\mathrm{LiCl}$ (see Fig. 1a).

Total RNA extraction. CTA, flavor-only, and toxin-only animals were used as behavioral groups for the real-time PCR study. For this experiment, three independent groups of RNA pools each from three rats were used as biological replicates (three pools of three animals each). Rats were decapitated $3 \mathrm{~h}$ after behavioral training, and their brains were rapidly dissected, chilled in ice-cold PBS, washed with stabilization reagent (RNAlater; QIAGEN), and then transferred to a rat brain matrix. Amygdalar-enriched tissue punches (3 mm wide) were collected from coronal brain slices using as a reference the rat brain map of Paxinos and Watson (1998), which locates the amygdala between -2.12 and -4.52 mm bregma points (see Fig. 1b). Amygdalar tissue from each behavioral group was pooled ( $n=3$ animals in each pool), and RNA extraction was done using an RNA isolation kit (QIAGEN) according to the manufacturer's instructions and as described by us (Peña de Ortiz et al., 2003; Robles et al., 2003). The concentration and integrity of RNA were determined using the NanoDrop-1000 Spectrophotometer (NanoDrop Technologies) and the 2100 Bioanalyzer (Agilent Technologies) with an RNA 6000 Nano LabChip kit (Agilent Technologies).

Primer design for real-time PCR. Sequences of genes analyzed [fen-1, accession no. AF281018; and glyceraldehyde 3-phosphate dehydrogenase ( gapdh), accession no. M17701] were obtained from GenBank. We used the Integrated DNA Technologies PrimerQuest and Oligo Analyzer programs to design specific primers suitable for real-time PCR and also avoid possible hairpins, dimers, and cross dimers. A BLAST (basic local alignment search tool) search was done on all primers to ensure that they would not potentially anneal to other targets. The following forward and reverse primers were used: fen-1, forward, 5'-ATTGCTGTTCGTCAGGGTGG-3'; fen-1, reverse, 5'-GGTCTCCCCCTCCTCGTTC-3'; gapdh, forward, 5'-ATGATTCTACCCACGGCAAG-3'; gapdh, reverse, 5'-CTGGAAGATGGTGATGGGTT-3' . All primers were synthesized by Sigma-Aldrich.

Real-time PCR. Amygdalar RNA from three independent pools, each composed of samples from three animals per behavioral group (CTA, flavor-only, and toxin-only), was used for the study of selected genes using real-time PCR. Animals were trained and killed at the $3 \mathrm{~h}$ time point as detailed above. For the antisense knockdown validation experiments (see antisense experiments below), amygdalar RNA was extracted from antisense and random oligonucleotide-treated animals $(n=4$ each), killed $3 \mathrm{~h}$ or $12 \mathrm{~d}$ after the last oligonucleotide infusion. cDNA was obtained from total RNA samples, extracted as detailed above, using the TaqMan reverse transcription (RT) reagents (Applied Biosystems). Briefly, $20 \mu \mathrm{l}$ of reaction mixture containing $20 \mathrm{ng}$ of RNA, $500 \mu \mathrm{M}$ of each dNTP, $1 \times$ TaqMan RT buffer, $25 \mathrm{~mm} \mathrm{MgCl}_{2}, 2.5 \mu \mathrm{M}$ random hexamers, $40 \mathrm{U}$ of RNase Inhibitor, and $125 \mathrm{U}$ of MultiScribe reverse transcriptase were incubated at $25^{\circ} \mathrm{C}$ for $10 \mathrm{~min}$ followed by incubation at $48^{\circ} \mathrm{C}$ for $40 \mathrm{~min}$. The reaction was stopped by incubating at $95^{\circ} \mathrm{C}$ for 5 min. To generate the standard curves, a pooled cDNA from the behavioral groups was synthesized and specific primers for fen-1 and gapdh were optimized to work under the same cycling conditions. Real-time PCR was performed using an iCycler iQ Real-time PCR Detection System (Bio-Rad) and the QuantiTect SYBR Green PCR kit (QIAGEN). Briefly, $250 \mathrm{ng}$ of cDNA were combined with $0.5 \mu \mathrm{M}$ of each primer, $1 \times$ QuantiTect SYBR Green PCR Master Mix (HotStarTaq DNA polymerase, quantiTect SYBR Green PCR buffer, dNTP mix, and SYBR Green I) and PCR-grade water to a volume of $25 \mu$ l. The cycling conditions for all primers were as follows: $95^{\circ} \mathrm{C}$ for $15 \mathrm{~min}$ to activate the HotStarTaq polymerase, followed by 40 cycles consisting of three steps, $45 \mathrm{~s}$ at $95^{\circ} \mathrm{C}$ (denaturation), $30 \mathrm{~s}$ at $58.5^{\circ} \mathrm{C}$ (annealing), and $30 \mathrm{~s}$ at $72^{\circ} \mathrm{C}$ (extension). The PCR program was completed by a melting temperature analysis consisting of $1 \mathrm{~min}$ at $95^{\circ} \mathrm{C}$ (denaturation), $2 \mathrm{~min}$ at $55^{\circ} \mathrm{C}$ (annealing), and then 101 steps lasting $8 \mathrm{~s}$ each, through which temperature ranged from 55 to $95^{\circ} \mathrm{C}$. Amplification plots were produced to calculate the threshold cycle $(\mathrm{Ct})$, and standard curves of Ct versus log cDNA dilution were generated for both target and reference genes. Since all reactions were done in triplicate, the average $\mathrm{Ct}$ and nanomoles were used for plotting and quantification. For quantification, we applied the standard curve method in which the quantity of the target gene was expressed relative to the amount of the reference gene. In this case, nanomoles of fen- 1 cDNA were divided by those of gapdh to obtain a normalized target expression value.

Protein extraction. CTA rats were decapitated $15 \mathrm{~min}, 30 \mathrm{~min}, 3 \mathrm{~h}$, or $3.5 \mathrm{~h}$ ( $n=3$ per time point) after training and their brains were obtained, chilled on ice-cold PBS, and used to dissect amygdala as previously explained, and also insular cortex between 1.70 and $0.70 \mathrm{~mm}$ bregma points. Amygdala or insular cortex tissue punches from three animals per time point were combined yielding one pool sample per group. Pooled tissue was stored at $-80^{\circ} \mathrm{C}$ until used for protein extraction. Protein extracts were prepared as described by us previously (Ren and Peña de Ortiz, 2002; Wang et al., 2003; Colón-Cesario et al., 2006a). Tissues were homogenized in extraction buffer [30 mM HEPES/KOH, pH 7.9, $0.5 \mathrm{~m}$ $\mathrm{KCl}, 5 \mathrm{~mm} \mathrm{MgCl}$, 1 mM EDTA, 2 mm dithiothreitol (DTT), 20\% glycerol, $1 \mathrm{~mm}$ phenylmethylsulfonyl fluoride (PMSF), and $1 \mu \mathrm{g} / \mathrm{ml}$ each of leupeptin and aprotinin] and incubated for $1 \mathrm{~h}$ in ice. The extract was centrifuged at $14,000 \mathrm{rpm}$ for $1 \mathrm{~h}$ at $4^{\circ} \mathrm{C}$. The supernatant was then dialyzed for $5 \mathrm{~h}$ in dialysis buffer (30 mM HEPES/KOH, pH 7.9, $50 \mathrm{~mm}$ $\mathrm{KCl}, 2$ mм EDTA, 5 mm $\mathrm{MgCl}_{2}$, 1 mм DTT, 10\% glycerol, 1 mm PMSF, and $1 \mu \mathrm{g} / \mathrm{ml}$ each of leupeptin and aprotinin). Dialyzed fractions were centrifuged at $14,000 \mathrm{rpm}$ for $30 \mathrm{~min}$ at $4^{\circ} \mathrm{C}$. Protein extracts were stored at $-80^{\circ} \mathrm{C}$ until used. The protein concentration was determined by the Bradford method as detailed by us previously (Ren and Peña de Ortiz, 2002; Wang et al., 2003; Colón-Cesario et al., 2006a).

Western blotting. Protein samples $(40 \mu \mathrm{g})$ were first separated on a $6 \%$ SDS-PAGE. The separated proteins in the gel were transferred to a nitrocellulose membrane using a semidry electroblotter system at $5 \mathrm{~V}$ and $4^{\circ} \mathrm{C}$ overnight. Then, the membrane was blocked with SuperBlock solution (Pierce) for $1.5 \mathrm{~h}$ at room temperature (rt) on an orbital shaker. After five washes of 5 min each with PBS-Tween 20 (PBS-T), the membrane was incubated with a 1:3000 dilution of a polyclonal antibody raised against a human Fen-1 peptide (Abcam) at $4^{\circ} \mathrm{C}$ overnight, washed with PBS-T and then incubated with 1:500 anti-rabbit HRP-conjugated secondary antibody for $1 \mathrm{~h}$. The membrane was soaked briefly with Supersignal WestPico Chemiluminescent Substrate (Pierce) for immune detection. For normalization purposes, membrane was stripped of antibodies and reprobed for $\beta$-actin as described previously (Ge et al., 2003; ColónCesario et al., 2006b). Membranes were analyzed using the Gel Doc System (Bio-Rad), and expression was normalized by dividing the mean optical densities of Fen-1-immunopositive signals per time point by the corresponding $\beta$-actin signal optical densities. These Western blot anal- 
yses were repeated three times in different gel runs and blots, respectively. Specificity of the Fen-1 antibody was demonstrated by preabsorption tests with Fen-1 peptide. Briefly, the Fen-1 polyclonal antibody was incubated during $4-5 \mathrm{~h}$ at $\mathrm{rt}$ in a dilution of $1: 8$ with the peptide derived from a portion of the latter one-half of the $\mathrm{N}$-terminal domain of human Fen-1, the same peptide from which the antibody used in our studies was raised (Abcam). Then, this antibody-peptide mix was used for Western blotting as above.

Immunofluorescence. To examine the cellular localization of Fen-1 expression, rats $(n=8)$ were decapitated $3.5 \mathrm{~h}$ after CTA training and their brains were immediately isolated, washed with ice-cold PBS, and stored at $-80^{\circ} \mathrm{C}$. Frozen coronal amygdalar sections $(20 \mu \mathrm{m}$ thick $)$ were obtained in a cryostat at $-20^{\circ} \mathrm{C}$, placed on positively charged glass slides (Probe-On Slides; Thermo Fisher Scientific), and used for immunofluorescence analysis. Briefly, sections were allowed to air dry for $20 \mathrm{~min}$, fixed with $2 \%$ paraformaldehyde during $20 \mathrm{~min}$, and then washed twice with PBS, 5 min each time. Permeabilization was done with $0.1 \%$ Triton $\mathrm{X}-100$ in $0.1 \%$ of sodium citrate for $5 \mathrm{~min}$ and washed as described above. The sections were then incubated with 5\% goat serum in PBS for $30 \mathrm{~min}$. Double immunofluorescence was performed, incubating the sections with primary anti-Fen-1 polyclonal antibody (Abcam) diluted at 1:250 in $1 \%$ goat serum/PBS together with primary anti-neuronal nuclei (NeuN) monoclonal antibody (Millipore) or primary anti-glial fibrillary acidic protein (GFAP) monoclonal antibody (Sigma-Aldrich), diluted at 1:100 and 1:400 in $1 \%$ horse serum/PBS, respectively. Sections were then incubated overnight at $4^{\circ} \mathrm{C}$ in a moist chamber. On the next, sections were washed twice in PBS and were incubated for $2 \mathrm{~h}$ at $\mathrm{rt}$ in a dark room with Alexa Fluor 488-conjugated goat anti-rabbit IgG (for detection of Fen-1) and Alexa Fluor 568-conjugated goat anti-mouse IgG (Invitrogen) (for detection of $\mathrm{NeuN}$ ), diluted both at 1:100 in 1\% goat serum/PBS, followed by PBS washing. Different sections were incubated with Alexa Fluor 568-conjugated goat anti-rabbit IgG for detection of Fen-1, and Alexa Fluor 488-conjugated donkey anti-mouse IgG for detection of GFAP, diluted both at 1:100 in $1 \%$ goat serum/PBS. The slides were mounted using permanent mounting medium (Vector Laboratories). All slides were first scanned at low magnification $(10 \times)$ to locate the amygdala, which was subsequently analyzed at higher magnification $(40 \times)$ using a Zeiss LSM-5 Pascal scanning confocal microscope. Final image composites were created using Zeiss LSM5 PASCAL Image software, version 3.2.

Cell culture, RNA isolation, real-time PCR, and confocal immunofluorescence microscopy. To examine the constitutive fen-1 expression of rat neuronal cells and astrocytes, fen-1 mRNA levels were measured in rat naive PC- 12 cells, PC- 12 cells differentiated to the neuronal phenotype, and DI TNC astrocytes, using real-time PCR. Rat pheochromocytoma PC-12 cells and rat DI TNC were obtained from American Type Culture Collection. PC-12 cells were cultured in F-12K medium (American Type Culture Collection) containing 15\% (v/v) horse serum (American Type Culture Collection) and 2.5\% (v/v) fetal clone III serum (FCIII) (Invitrogen). Rat DI TNC immortalized astrocytes (American Type Culture Collection) were maintained in DMEM (Invitrogen), containing 5\% (v/v) FCIII (Invitrogen). All culture media were supplemented with 1\% streptomycin and $1 \%$ penicillin obtained from Sigma-Aldrich, and cells were cultured at $37^{\circ} \mathrm{C}$ in a humidified atmosphere of $5 \% \mathrm{CO}_{2}$.

Total RNA was isolated from naive PC-12 cells, PC-12 cells differentiated to neuronal phenotype with $100 \mathrm{ng}$ of staurosporine (SigmaAldrich), as well as DI TNC cells ( $n=3$ independent experiments), using the Trizol reagent following the manufacturer's instructions (Invitrogen). For real-time PCR, $1 \mathrm{mg}$ of total RNA was obtained from DI TNC cells, naive PC-12 cells and differentiated PC-12 cells. cDNAs were derived using the Reverse Transcription System kit from Promega following the manufacturer's instructions. Real-time PCR for detection of fen-1 and gapdh was performed as previously described in this section.

Immunofluorescence analysis was used to visualize cellular morphology. Briefly, PC-12 and DI TNC cells were plated on two-well Laboratory-Tek chamber slides (Nalge Nunc International) at a density of $1 \times 10^{5}$ cells/well for $48 \mathrm{~h}$ before imaging. In addition, PC- 12 cells were treated with $100 \mathrm{ng}$ of staurosporine for an extra $24 \mathrm{~h}$ to achieve homogenous population of neurons. Next, cells were fixed for $10 \mathrm{~min}$ in
PBS containing 3.7\% formaldehyde, washed with PBS, permeabilized with $0.1 \%(\mathrm{v} / \mathrm{v})$ Triton X-100 in PBS for $3 \mathrm{~min}$, and washed three times with PBS. Then, they were incubated with $5 \%$ horse serum (Invitrogen) for $30 \mathrm{~min}$ followed by incubation with $5 \mathrm{U}$ of Alexa Fluor 488conjugated phalloidin (Invitrogen) in 5\% horse serum to visualize F-actin and washed. Images were acquired as described previously using a Zeiss LSM-5 Pascal scanning confocal microscope equipped with an Alpha-Fluor $100 \times 1.45$ differential interference contrast oil-immersion objective. Final image composites were created using Zeiss LSM5 PASCAL Image software, version 3.2.

fen-1 antisense oligonucleotides. Gapmer antisense oligonucleotides were designed to target the start codon of rat fen-1 mRNA. This 21 bp gapmer contains a central block of phosphorothioate-deoxynucleotides, sufficient to induce RNase $\mathrm{H}$ cleavage, flanked by blocks of 2'-O-methyl-modified ribonucleotides that protect the internal block from nuclease degradation. As a control, a random sequence was also designed with the same backbone modifications and base composition as fen- 1 antisense, but in a scrambled order and without homology to any known rat gene. fen-1 antisense and random oligonucleotide sequences were as follows: $5^{\prime}-m C m A m U m G m G T^{*} A^{*} A^{*}$ $\mathrm{C}^{\star} \mathrm{A}^{\star} \mathrm{C}^{\star} \mathrm{A}^{\star} \mathrm{G}^{\star} \mathrm{G}^{\star} \mathrm{A}^{\star} \mathrm{G}^{\star} \mathrm{mCmAmAmUmG}-3^{\prime}$ and $5^{\prime}-\mathrm{mAmCmGmCmAA^{* }}$ $\mathrm{G}^{\star} \mathrm{A}^{\star} \mathrm{T}^{\star} \mathrm{C}^{\star} \mathrm{G}^{\star} \mathrm{A}^{\star} \mathrm{G}^{\star} \mathrm{A}^{\star} \mathrm{C}^{\star} \mathrm{T}^{\star} \mathrm{mAmGmGmAmU}-3^{\prime}$, respectively (where $\mathrm{m}$ represents $2^{\prime}$-O-methyl RNA, and ${ }^{\star}$ represents phosphorothioate DNA). Antisense and random sequences were synthesized by Integrated DNA Technologies. All three batches of antisense and random oligonucleotides used to complete these studies were received lyophilized and fully purified by HPLC. Oligonucleotides were dissolved in sterile $0.9 \%$ saline solution to a final concentration of $2 \mathrm{nmol} / \mu \mathrm{l}$.

Surgery. Rats were handled for 2-3 d before undergoing surgery, following similar methods as those described by us previously (Wang et al., 2003; Vázquez and Peña de Ortiz, 2004; Colón-Cesario et al., 2006b). For surgery, animals were anesthetized with sodium pentobarbital $(50 \mathrm{mg} /$ kg, i.p.), and placed into a stereotaxic apparatus (David Kopf Instruments), with the nose angled at $0^{\circ}$. After a scalp incision was made, lambda and bregma were located, and holes were drilled in the skull above the target region. Bilateral guide cannulae ( $8 \mathrm{~mm}$ long) were implanted above the basolateral amygdala (BLA) complex using the following coordinates: anterior-posterior, $-3.4 \mathrm{~mm}$ from bregma; mediolateral, $5.0 \mathrm{~mm}$ from midline; dorsoventral, $-7.6 \mathrm{~mm}$ from skull. The cannulae were secured to stainless-steel screws with dental cement and a light-curable resin. Wire stylets were inserted into the guides and checked every day to ensure clean and functional cannulae. After surgery, animals were allowed to recover for $4 \mathrm{~d}$ before behavioral experiments.

Diffusion studies. After cannulae implantation, injectors were inserted and animals $(n=4)$ were infused with FITC-fen- 1 antisense to estimate the area of the antisense diffusion within the amygdala. An infusion of 1 $\mu l$ of FITC-fen- 1 antisense oligonucleotide $(2 \mathrm{nmol}$ ) was delivered bilaterally into the amygdala during a $2 \mathrm{~min}$ period at a rate of $0.5 \mu \mathrm{l} / \mathrm{min}$. Animals were decapitated $4 \mathrm{~h}$ after infusion, and their brains were isolated and stored at $-80^{\circ} \mathrm{C}$. Coronal amygdalar sections, $20 \mu \mathrm{m}$ thick, were visualized using a fluorescence microscope (Pixcell II; Arcturus), and digitalized photomicrographs were obtained.

Intraamygdalar infusions, behavioral training, and memory testing. To assess the effectiveness of the infusion pump system and to adapt the animals to receive intraamygdalar infusions, rats were subjected to bilateral infusions ( $2 \mathrm{~min}$ at $0.5 \mu \mathrm{l} / \mathrm{min}$ ) of $0.9 \%$ saline on the day before conditioning. The infusion was accomplished by inserting a 30 gauge stainless-steel injector into the guide cannulae so that it extended $1 \mathrm{~mm}$ beyond the tip of the guide, right above the targeted amygdalar regions. For the behavioral training, rats were habituated during $4 \mathrm{~d}$ as previously described in the CTA protocol above, and on day 5 , animals were infused bilaterally into the amygdala with $1 \mu \mathrm{l}$ of fen-1 antisense or random oligonucleotides, $1 \mathrm{~h}$ before dextrose (CS) presentation. A second oligonucleotide infusion, either fen- 1 antisense or random oligonucleotides (1 $\mu \mathrm{l}$ each), was delivered to animals of both groups $1 \mathrm{~h}$ after $\mathrm{LiCl}$ injection (US). A set of animals receiving either fen-1 antisense or random oligonucleotide infusions ( $n=6$ in each group) into the amygdala, as detailed above, were subjected to a short-term memory (STM) test $2 \mathrm{~h}$ after conditioning. During the test, the animals were presented with a choice of plain water and dextrose solutions for $10 \mathrm{~min}$. Liquid consumption 
a

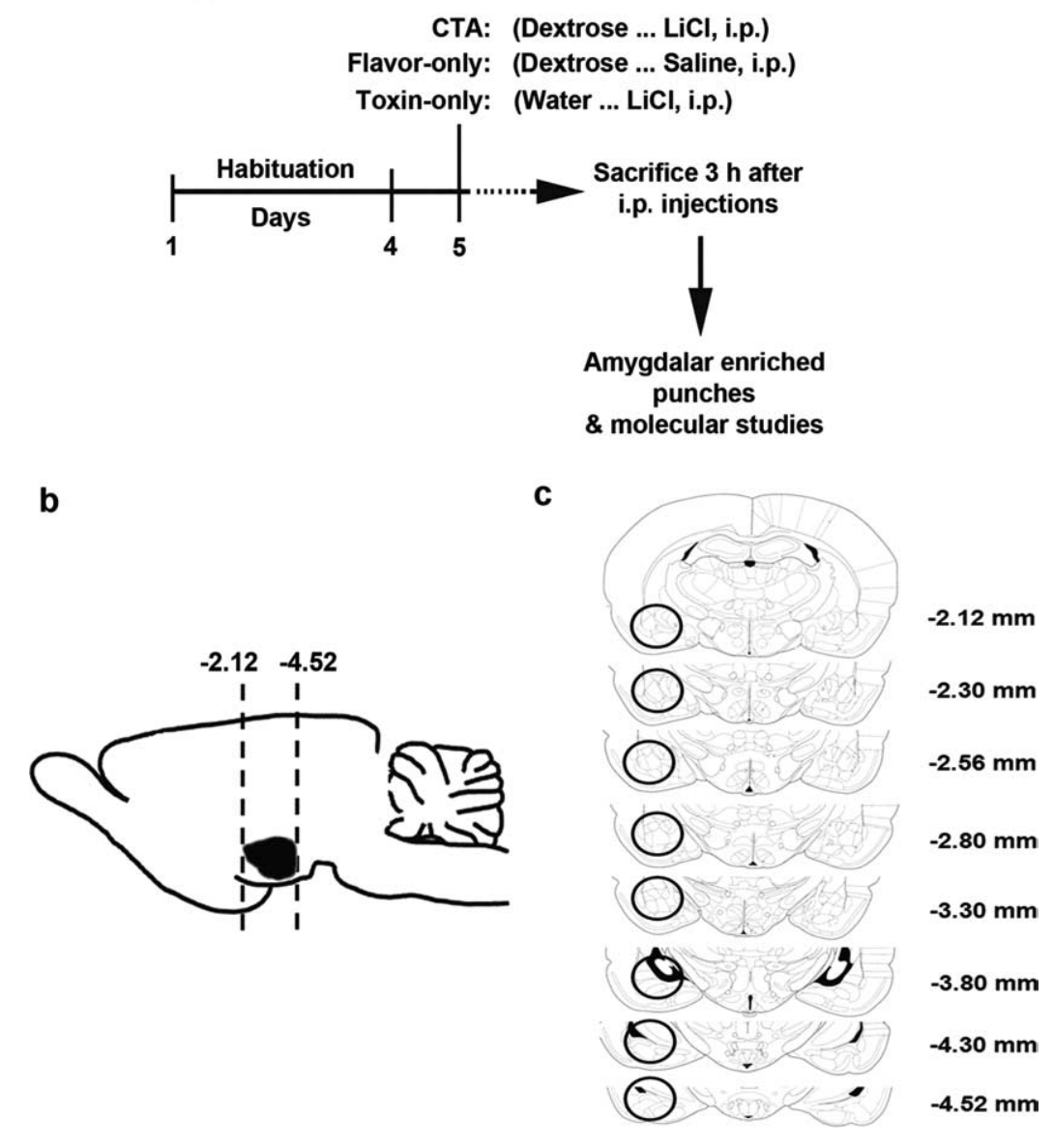

Figure 1. Strategy for analysis of fen-1 expression in the amygdala after CTA. $\boldsymbol{a}$, Schematic diagram depicting our experimental design. Rats were habituated for $4 \mathrm{~d}$, and on day 5 , the conditioning day, they were divided into three behavioral groups: CTA, flavor-only, and toxin-only groups ( $n=3$ rats each). Three hours after training, animals were decapitated, and their brains were used to collect amygdalar-enriched tissue punches for molecular studies. $\boldsymbol{b}$, Sagittal view of the rat brain, localizing the amygdala between -2.12 and $-4.52 \mathrm{~mm}$ bregma points, according to the rat brain map of Paxinos and Watson (1998). Amygdalarenriched tissue punches were collected from brain slices obtained using these coordinates. $c$, Schemes of coronal sections of the rat brain showing the localization of the amygdala between -2.12 and $-4.52 \mathrm{~mm}$ bregma points. These coordinates were used as reference to extract the amygdalar tissue. The amygdala in each section is pointed out with a circle.

was measured by weighing the drinking bottles before and after consumption. Associative learning and memory were assessed by the aversion to the CS, measured as an aversion index calculated as follows: water intake/ (water intake + dextrose intake).

CTA memory consolidation was tested in a separate set of animals $(n=11$ in each group; antisense or random oligonucleotide-treated animals) $48 \mathrm{~h}$ after conditioning. Aversion indexes were calculated as described for the short-term memory test. Twelve days after the LTM test, these previously infused animals were subjected to a new CTA training experience using $0.1 \%$ glycine as the CS. No oligonucleotide brain infusions were delivered during this conditioning, and the new CTA memory was also tested $48 \mathrm{~h}$ after training. In a separate control experiment, a new group of untrained animals received fen-1 antisense or random $(n=4)$ oligonucleotide amygdalar infusions, and using real-time PCR, the amygdalar fen-1 mRNA levels were measured 12 d later (corresponding to the start of the second CTA in the experiment above).

Statistical analysis. All statistical analyses were performed with Prism 4 software (GraphPad Software). For all the behavioral and molecular experiments, we assumed statistical significance at $p<0.05$. In the realtime PCR studies, one-way ANOVA and Newman-Keuls posttests were used to compare fen-1 mRNA expression between behavioral groups. Two-way ANOVA and Bonferroni's posttesting were applied to analyze the results from the Western blotting experiments as well as the differences in terms of the aversion index in the STM and LTM tests between fen-1 antisense and random oligonucleotidetreated rats. The constitutive levels of fen-1 mRNA measured by real-time PCR in different cell types were examined using one-way ANOVA and Newman-Keuls posttest. Twoway ANOVA and Bonferroni's posttesting were also used in the LTM data, but only to determine differences in CS consumption. Finally, fen-1 mRNA expression measured by real-time PCR between fen-1 antisense and random-treated animals was examined using Student's t tests.

\section{Results \\ fen-1 mRNA is induced in the amygdala as a result of CTA}

For these studies, we decided to focus on fen-1, a flap structure-specific endonuclease involved in different aspects of DNA metabolism, including recombination/repair. Initially, we used quantitative realtime PCR to determine whether the expression of $f e n-1$ is modulated in the amygdala in association to CTA. The experimental design used in this study is depicted in Figure $1 a-c$. A preliminary time course study identified changes in amygdalar fen-1 mRNA levels $3 \mathrm{~h}$, but not $1 \mathrm{~h}$, after CTA training (data not shown). Moreover, previous studies by us have identified important changes in gene expression and function related to learning and memory processes, including CTA (Ge et al., 2003), both in the amygdala or the hippocampus $3 \mathrm{~h}$ after behavioral training (Peña de Ortiz et al., 2000; Robles et al., 2003). For that reason, we decided to focus on the $3 \mathrm{~h}$ time point for these studies. Amplification and melting temperature curves of fen-1 and gapdh (the control housekeeping gene) are depicted to show the cycle thresholds $(\mathrm{Ct})$ for both genes (Fig. $2 a$ ) and to determine that only one product per gene was generated (Fig. $2 b$ ). As seen in Figure $2 c$, the results showed that amygdalar gapdh mRNA levels (measured by the Ct values) were similar between the three groups examined, CTA, flavor-only, and toxin-only (one-way ANOVA, $F_{(2,35)}=0.14 ; p>0.05$ ). In contrast, for fen-1 mRNA (Fig. $2 d$ ), one-way ANOVA detected significant differences between the groups after normalization with the standard curve $\left(F_{(2,17)}=3.97 ;{ }^{\star} p=0.0412\right)$. Newman-Keuls determined that amygdalar fen-1 mRNA expression was significantly higher in CTA-trained animals compared with flavor-only rats $\left({ }^{*} p<\right.$ $0.05)$. No specific significant differences were observed in the amygdalar expression of fen-1 mRNA between CTA and toxin-only groups $(p>0.05)$ or between flavor-only and toxin-only groups $(p>0.05)$. Overall, these results indicate that higher amygdalar fen- 1 mRNA levels are associated to CTA $3 \mathrm{~h}$ after training, probably also related to the illness component of this conditioning.

Fen-1 protein shows regionally specific induction as a result of CTA

CTA-trained animals were decapitated $15 \mathrm{~min}, 30 \mathrm{~min}, 3 \mathrm{~h}$, or $3.5 \mathrm{~h}$ ( $n=3$ per time point) after conditioning, and protein extracts from amygdala and insular cortex, a brain region also 
related to CTA (Gallo et al., 1992; Bermúdez-Rattoni and Yamamoto, 1998), were used for Fen-1 detection by Western blotting. We chose to examine Fen-1 protein expression at these particular time points because we wanted to determine whether there was a contrast between early Fen- 1 expression seen at 15 or 30 min after training versus the expression of the protein based on the mRNA upregulation seen in our real-time PCR studies $3 \mathrm{~h}$ after CTA. In fact, we decided to use the $3.5 \mathrm{~h}$ time point because the previous data were obtained based on mRNA levels and we anticipated that the protein might follow a more delayed course of induction. Results revealed that Fen-1 was indeed induced in the amygdala between 3 and $3.5 \mathrm{~h}$ after training, compared with the earlier time points (Fig. $3 a$ ), in agreement with our previous findings with fen-1 mRNA. No Fen-1 induction was detected in the insular cortex (Fig. $3 b$ ) as a result of CTA. The specificity of the Fen-1 antibody used in these studies was confirmed using Fen-1 peptide preabsorption assays (Fig. 3c). Quantitative and statistical analysis of Fen-1 signals (Fig. 3d) showed significant differences in Fen-1 levels between the groups (two-way ANOVA: time factor, $F_{(3,16)}=5.11,{ }^{*} p=0.0114$; region factor, $\left.F_{(1,16)}=15.99,{ }^{* *} p=0.001\right)$, with no significant interaction between the time and region factors $\left(F_{(3,16)}=1.397 ; p=\right.$ $0.2801)$. Bonferroni's posttesting indicated specific significant differences in Fen-1 within the amygdala, but not the insular cortex, when comparing the $3.5 \mathrm{~h}$ versus the $15 \mathrm{~min}\left({ }^{* *} p<0.01\right)$, $30 \mathrm{~min}\left({ }^{++} p<0.01\right)$, and $3 \mathrm{~h}\left({ }^{\circledR} p<0.05\right)$ time points. The results indicate that the training-induced upregulation of the fen-1 gene occurs both at the mRNA and protein levels and that such induction is specific to the amygdala, compared with the insular cortex.

\section{Fen-1 protein is localized within amygdalar neuronal cells}

Fen-1 is an endonuclease involved in several DNA metabolism processes common for all types of cells, such as Okazaki fragment removal during replication, long-patch base excision repair, NHEJ, and homologous recombination (Liu et al., 2004; Shen et al., 2005; Casta et al., 2008). Hence, we considered it important to establish the cell type specificity of Fen-1 after CTA and determine whether it is expressed by neurons, glial cells, or both. Based on its known role in DNA replication, we did expect to see Fen-1 expression in glial cells. However, based on its upregulation after CTA learning, we also expected to see Fen-1 expressed in neurons.

Double immunofluorescence of Fen-1 antibody with the neuronal marker, NeuN, or the astrocytic marker, GFAP, was performed on amygdalar sections from CTA animals $(n=8)$ decapitated $3.5 \mathrm{~h}$ after training. Using confocal microscopy, we examined amygdalar sections double-labeled with Fen-1 (Alexa Fluor 488; green signal) and NeuN (Alexa Fluor 568; red signal) (Fig. 4a). These immunofluorescent images show colocalization of Fen-1-expressing cells with those expressing NeuN, indicating the presence of Fen-1 in neurons. In contrast, images from amyg- b

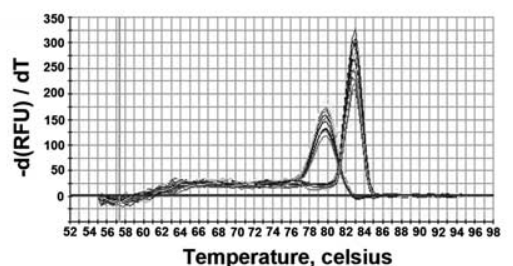

d

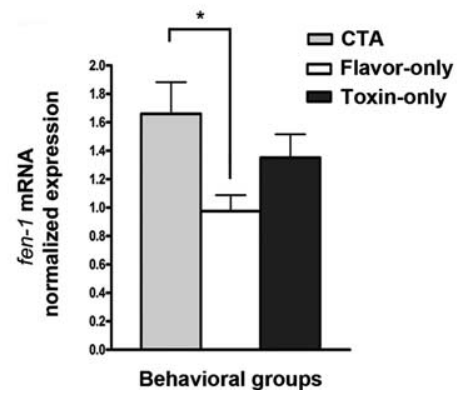

Figure 2. Training-induced upregulation of fen-1 gene occurs at mRNA level in the amygdala. Real-time PCR for fen-1 mRNA detection was performed in amygdalar cDNA samples from CTA, flavor-only, and toxin-only animals ( $n=3$ rats per group) decapitated $3 \mathrm{~h}$ after training. $\boldsymbol{a}$, Amplification curves for fen-1 (right) and gapdh (left) were obtained to identify the cycle (2,35) $=0.14 ; p>0.05)$. $\boldsymbol{d}$, Bar graphs depicting amygdalar fen-1 normalized expression in (TA significant differences between the CTA and flavor-only groups ( $\left.{ }^{*} p<0.05\right)$, but not between (TA and toxin-only groups, or between flavor-only and toxin-only groups. Error bars indicate SEM.

dalar sections double-labeled with Fen-1 (Alexa Fluor 568; red signal) and GFAP (Alexa Fluor 488; green signal) suggest that Fen-1-expressing cells differ in localization and morphology with the GFAP-expressing cells (Fig. 4b,c). While the immunofluorescence signal for Fen-1 corresponds to large and round cells, the GFAP-positive cells display the distal processes distinctive of astrocytes, with relatively small cell bodies and long intermediate filaments. For example, Figure $4 c$ shows how Fen-1-positive cells (labeled with Alexa Fluor 568) are wrapped and surrounded by GFAP-positive cells (Alexa Fluor 488). These findings indicate that Fen-1 appeared to be expressed predominantly in neurons, as suggested by the colocalization between Fen-1 and NeuN.

Although Fen-1 protein expression was not detected in astrocytes using this immunofluorescence analysis, we examined the basal fen-1 mRNA levels in cultured rat neuronal cells and astrocytes to compare the constitutive Fen-1 expression in both types of cells. For this, fen-1 mRNA expression was measured in rat naive PC- 12 cells, PC- 12 cells differentiated to the neuronal phenotype, and DI TNC astrocytes, using real-time PCR. As seen in Figure $5 a$, one-way ANOVA detected significant differences in fen-1 mRNA levels between the groups $\left(F_{(2,17)}=6.180\right.$; ${ }^{\star} p=$ 0.011). Newman-Keuls determined that constitutive fen-1 mRNA levels are significantly higher in the PC-12 neuronal cells compared with the naive PC-12 cells $\left({ }^{*} p<0.05\right)$ and the DI TNC astrocytes $\left({ }^{* *} p<0.01\right)$. No statistical significance was found in fen-1 mRNA levels between naive PC-12 cells and the DI TNC astrocytes $(p>0.05)$. The morphology of the three cell types used in this study can be appreciated in Figure $5 b$. These results confirm that, although Fen-1 is constitutively ex- 
a

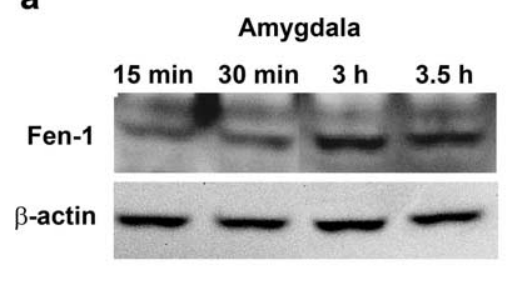

C

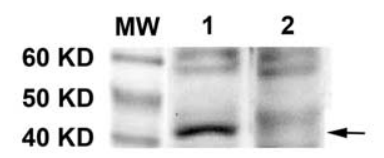

Antibody preabsorption control b

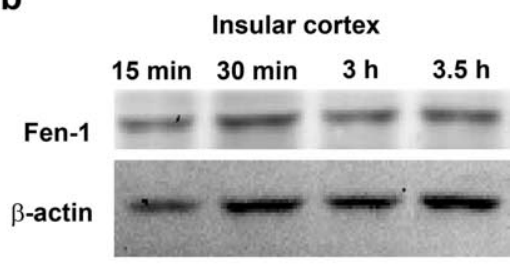

d

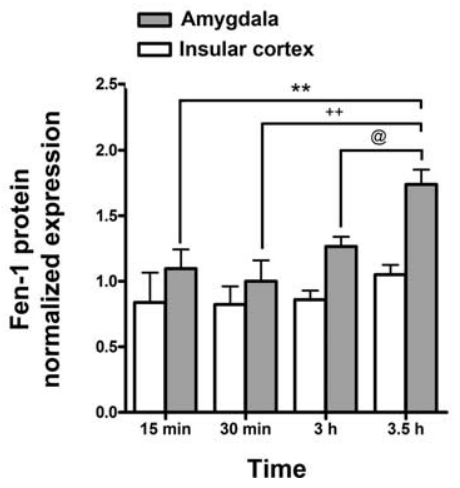

Figure 3. Fen-1 protein analysis after CTA training. CTA-trained rats were decapitated $15 \mathrm{~min}, 30 \mathrm{~min}, 3 \mathrm{~h}$, or $3.5 \mathrm{~h}$ ( $n=3$ rats per time point) after training, and their brains were isolated to collect amygdalar and insular cortex enriched tissue punches. Protein extracts from these regions were prepared for Fen-1 detection using Western blotting. Representative Western blots show Fen-1 and $\beta$-actin levels in the amygdala ( $\boldsymbol{a}$ ) and the insular cortex $(\boldsymbol{b})$. Fen-1 was specifically induced in the amygdala between 3 and 3.5 h after conditioning. $c$, Western blot showing Fen- 1 antibody specificity. A preabsorption assay using Fen-1 peptide and the antibody generated through this immunogen shows the specificity of the antibody against Fen-1 protein. M, Marker; 1, Fen-1 signal (42 kDa) in absence of peptide; 2, loss of Fen-1 signal after preincubation of Fen-1 peptide with its antibody. $\boldsymbol{d}$, Bar graphs presenting the quantitative analysis of Fen-1 normalized signals in the amygdala (gray bars) and in the insular cortex (white bars) after training. Two-way ANOVA detected significant differences in Fen-1 expression in the amygdala, but not in the insular cortex, when comparing the $3.5 \mathrm{~h}$ versus the $15 \mathrm{~min}\left({ }^{* *} p<0.01\right), 30 \mathrm{~min}\left({ }^{++} p<0.01\right)$, and $3 \mathrm{~h}\left({ }^{@} p<0.05\right)$ time points. Error bars indicate SEM.

pressed in astrocytes, this basal glial expression is significantly lower than the basal Fen-1 neuronal expression.

\section{Fen-1 plays a role in consolidation of CTA}

The previous gene expression experiments demonstrated that fen- 1 is induced in the amygdala $3 \mathrm{~h}$ after CTA training, although the animals subjected only to the illness component of CTA also showed a tendency to have high fen-1 mRNA levels. Previous studies support the idea that the processing of the US in CTA is critical for overall associative learning in this paradigm (Lamprecht and Dudai, 1996; Swank et al., 1996; Yasoshima et al., 2006). Thus, we considered it essential to determine the functional role of fen-1 in the consolidation of CTA memory. We used an antisense approach to knockdown fen-1 expression in the amygdala and examined its effects on CTA memory formation.

Animals were implanted with bilateral cannulae directed to the BLA complex. We focused on the BLA, not only because this region has been shown to be involved in CTA consolidation (Schafe et al., 1998; Morris et al., 1999; Rollins et al., 2001), but also because several studies suggest that CTA acquisition and consolidation require neurotransmission involving inputs from the BLA onto the insular cortex (Bermúdez-Rattoni and McGaugh, 1991). We did not target Fen-1 expression in the insular cortex because of our findings with the Western blot analyses, which showed that no changes in Fen-1 expression occurred as a result of CTA in this cortical region. Representative photomicrographs and schematics illustrating the distribution of cannula placements throughout the amygdala for animals used in our behavioral experiments are included in Figure 6, $a$ and $b$. Since no behavioral differences were observed, regardless of the diverse

cannulae positions, behavioral data from all animals were used (see below). We also examined the diffusion of fen-1 antisense oligonucleotides in the amygdala (Fig. $6 c, d)$ through consecutive rostrocaudal sections. Diffusion of the infused FITCfen-1 antisense oligonucleotide was concentrated within the anterior, posterior, and ventral BLA. The antisense also extended into other amygdalar areas, including the medial $(\mathrm{CeM})$ and capsular $(\mathrm{CeC})$ divisions of the central amygdala (CeA), the anterior basomedial (BMA), the posterior basomedial (BMP), and the ventromedial lateral amygdala (LaVM). This FITC-fen-1 antisense oligonucleotide was clearly incorporated into the cells within these regions (Fig. 6e).

We next evaluated the effects of amygdalar fen-1 knockdown on CTA STM as well as LTM (Fig. 7a). Different sets of rats were used for each memory test to avoid potential confounding effects related to aversive extinction processes. For the STM test, rats were infused bilaterally with $\mathrm{fen}-1$ antisense $(n=6)$ or random oligonucleotides $(n=6) 1 \mathrm{~h}$ before the CS and $1 \mathrm{~h}$ after the US, and the memory test was done $2 \mathrm{~h}$ after conditioning. For the LTM test, rats were infused bilaterally with fen-1 antisense $(n=11)$ or random $(n=11)$ oligonucleotides $1 \mathrm{~h}$ before the $\mathrm{CS}$ and $1 \mathrm{~h}$ after the US, and the memory test was done $48 \mathrm{~h}$ after conditioning. We then subjected the behavioral data (Fig. $7 b$ ) to a two-way ANOVA analysis that found a significant effect caused by the oligonucleotide treatment $\left(F_{(1,29)}=9.834 ;{ }^{* *} p=\right.$ $0.0039)$, and a significant interaction between the oligonucleotide treatment and the type of memory test (STM vs LTM) $\left(F_{(1,29)}\right.$ $\left.=6.677 ;{ }^{\star} p=0.0151\right)$. Moreover, Bonferroni's posttesting identified a significant difference in terms of the aversion index between oligonucleotide treatments only in the LTM test $\left({ }^{* *} p<\right.$ 0.01 ). Specifically, the $f e n-1$ antisense-treated rats displayed a significantly lower aversion to dextrose than the random-treated animals, $48 \mathrm{~h}$ after conditioning. Overall, we determined that the amygdalar fen-1 antisense oligonucleotide treatment had no effect on STM, but significantly impaired LTM.

This effect was also observed when comparing dextrose consumption between antisense and random oligonucleotidetreated animals during the conditioning day and the LTM test (Fig. 7c) (two-way ANOVA: dextrose consumption factor, $F_{(1,40)}$ $=18.34 ;{ }^{* *} p=0.0001$; testing factor, $F_{(1,40)}=1.596 ; p=0.2138$; interaction effect, $\left.F_{(1,40)}=7.690 ;{ }^{* *} p=0.0084\right)$. The data presented here correspond to the animals used for the LTM test only. During conditioning, both groups of animals consumed similar amounts of dextrose, showing that the antisense-treated rats were not sick because of the intraamygdalar infusions. However, $48 \mathrm{~h}$ after conditioning, the antisense group consumed more dextrose than the random-treated group (Bonferroni's posttesting, ${ }^{*} p<$ 0.05 ), indicating that the antisense animals displayed poor memory of their aversive experience.

To examine potential nonspecific impairments that could be caused by the antisense treatment, the same antisense and random-treated animals used for the LTM test were subjected to 
a second CTA using glycine as the CS. This type of behavioral control has been previously used by us for the assessment of the potential long-term effects of blocking a CTA experience (Wang et al., 2003). Habituation for this new training was initiated 1 week after the first behavioral test. The second conditioning, now in the absence of new intraamygdalar oligonucleotide infusions, was given $12 \mathrm{~d}$ after the LTM test of the first CTA. This time delay between the two CTA trainings was used considering the fact that gapmer antisense oligonucleotides, such as those used here, have been detected in the brain several days after administration (Zhang et al., 1995). In addition, we considered it unlikely that by the time animals were subjected to the second CTA they would still present residual molecular effects because of either the antisense treatment or the training related to the first CTA experience. More specifically, we did not expect that any changes in Fen- 1 expression in antisense or random-treated rats occurring as a result of the first CTA experience would still be present during the second CTA training. This is in fact what we observed (see below).

The behavioral results of the second CTA experiment were the following. No significant differences in the aversion to the new CS were detected between the groups (Student's $t$ test: random, $0.8072 \pm$ 0.02170 vs $f e n-1$ antisense, $0.7796 \pm$ $0.02770 ; t_{(20)}=0.7835 ; p=0.4425 ; n=$ 11). These findings demonstrate that the animals previously infused with the antisense oligonucleotide were capable of forming and recalling a new aversive experience when this second CTA was performed without targeting fen-1 expression. Thus, any antisense-related irreversible damage on the neural circuits involved in CTA is unlikely.

In addition, we performed real-time PCR experiments to determine the effectiveness of the antisense oligonucleotide treatment on knockdown fen-1 mRNA expression in the amygdala. Rats were infused $1 \mathrm{~h}$ before the CS and $1 \mathrm{~h}$ after the US with bilateral fen-1 antisense or random oligonucleotides. Amygdalar fen-1 mRNA expression was first analyzed in trained rats decapitated $3 \mathrm{~h}$ after the last infusion. fen-1 mRNA was normalized against gapdh mRNA, which remained constant in both groups (Student's $t$ test: random, $21.63 \pm 0.3746$ vs fen- 1 antisense, $\left.22.24 \pm 0.5122 ; t_{(20)}=0.9684 ; p=0.3444 ; n=4\right)$. In contrast, after quantification and normalization of amygdalar fen-1 mRNA for both antisense and random-treated animals, we found that the antisense treatment caused a significant decrease in fen-1 mRNA (Student's $t$ test: random, $0.8792 \pm 0.03149$ vs fen- 1 antisense, $\left.0.5913 \pm 0.04313 ; t_{(26)}=5.24 ;{ }^{* *} p=0.0001 ; n=4\right)$. These results show the effectiveness and selectivity of the antisense treatment on knockdown fen-1 expression.

Finally, we wanted to verify that fen- 1 amygdalar mRNA levels at the time of the second CTA were similar between animals treated with antisense or random oligonucleotides in their first
CTA test (Fig. $7 b, c)$. Here, rats were infused bilaterally with fen-1 antisense $(n=4)$ or random $(n=4)$ oligonucleotides, but in the absence of behavioral training. These animals were placed in their home cages and $12 \mathrm{~d}$ later were killed to obtain amygdalar RNA. fen-1 mRNA levels were normalized against those of gapdh, which remained constant in both groups (Student's $t$ test: random, $29.96 \pm 0.2332$ vs fen- 1 antisense, $29.80 \pm 0.07326 ; t_{(6)}=$ $0.6342 ; p=0.5494 ; n=4)$. After quantification and normalization of amygdalar fen-1 mRNA for both antisense and randomtreated animals, we found no differences between the groups (Student's $t$ test: random, $0.5428 \pm 0.04966$ vs fen- 1 antisense, $\left.0.5300 \pm 0.04708 ; t_{(6)}=0.1863 ; p=0.8583 ; n=4\right)$. Thus, we can conclude that the lack of behavioral differences between groups in the second CTA experiment (Fig. $7 b$ ) was not attributable to any long-term effects of the antisense treatment. Overall, our findings demonstrate that the Fen-1 endonuclease is required for normal consolidation of CTA.

\section{Discussion}

Together with epigenetic (Korzus et al., 2004; Levenson and Sweatt, 2005; Vecsey et al., 2007), transcriptional (Squire and Barondes, 1970; Alberini et al., 1994; Silva et al., 1998), and translational (Schafe and LeDoux, 2000; Scharf et al., 2002; Quevedo et al., 2004) gene regulatory mechanisms, DNA recombination/re- 
a

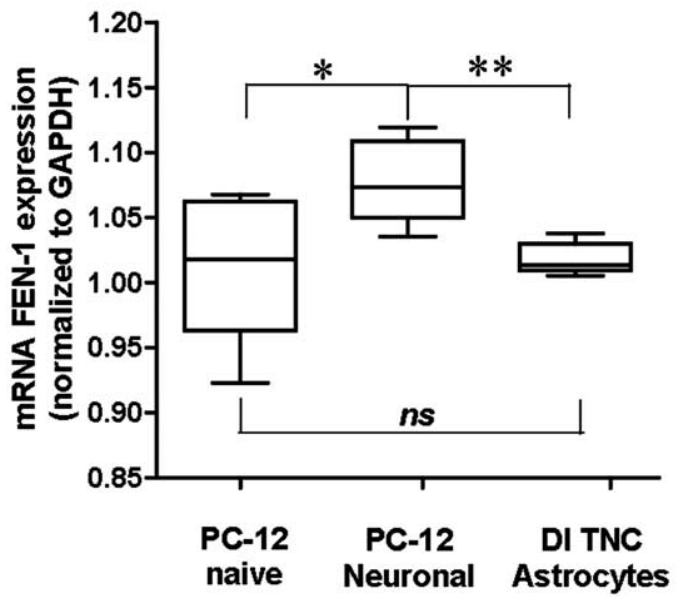

b
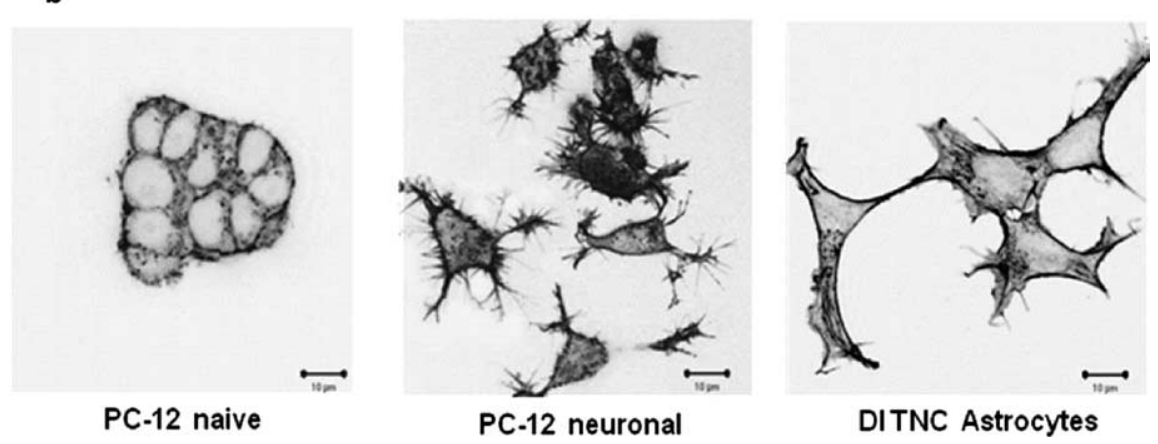

Figure 5. Comparative analysis of fen-1 gene expression in DI TNC astrocytes, naive PC -12 cells, and PC- 12 cells differentiated to the neuronal phenotype. $\boldsymbol{a}$, The standard curve method of relative quantification was used to calculate gene expression levels. The means of amplification data for fen- 1 expression relative to gapdh are shown as whisker box plots ( $n=6,2$ replicates for 3 independent experiments). The top and bottom whiskers indicate 95 th and 5 th percentiles, respectively; the lines inside the boxes indicate the median. One-way ANOVA detected significant differences in fen- 1 mRNA levels between the groups $\left(F_{(2,17)}=6.180\right.$; $\left.{ }^{*} p=0.011\right)$. Newman-Keuls determined that constitutive fen- 1 mRNA levels are significantly higher in the $P C-12$ neuronal cells compared with the naive PC -12 cells $\left({ }^{*} p<0.05\right)$ and the DI TNC astrocytes ( $\left.{ }^{* *} p<0.01\right)$. No significance (ns) was found between fen- 1 mRNA levels of naive PC-12 cells and the DI TNC astrocytes $(p>0.05) . \boldsymbol{b}$, Confocal immunofluorescence images (showing F-actin) of DI TNC astrocytes, naive PC -12 cells, and PC-12 cells differentiated to neuronal phenotype taken at magnification of $100 \times$ before comparative analysis of fen- 1 expression and presented in inverted grayscale mode for better visualization. Scale bar, $10 \mu \mathrm{m}$.

pair processes may contribute to LTM formation (Crick, 1984; Peña de Ortiz and Arshavsky, 2001). DNA recombination/repair processes require cutting, processing, and rejoining of DNA by endonucleases, polymerases, and ligases, among other factors (Bassing et al., 2002; Gellert, 2002; Pavlov et al., 2006). Here, we focused on Fen-1, a flap structure-specific endonuclease involved in several DNA metabolic pathways such as replication, recombination, and repair (Liu et al., 2004; Shen et al., 2005; Casta et al., 2008).

Fen-1 is upregulated in the amygdala in association to CTA Using real-time PCR, we compared amygdalar fen-1 expression of CTA-trained animals with that of animals subjected to the individual components of this aversive learning paradigm: flavor or illness. Interestingly, we found that fen-1 mRNA levels are significantly higher in CTA-trained animals compared with the flavor-only, but not with the toxin-only rats. This suggests that fen- 1 is induced in the amygdala after CTA and that such induction could be associated to the illness component of the paradigm. The finding that the illness component of CTA causes changes in gene expression in the amygdala is consistent with reports by others. Specifically, studies have demonstrated that the amygdala is involved in processing and storing information about the illness component of CTA (Yamamoto et al., 1992; Gu et al., 1993; Lamprecht and Dudai, 1996; Swank et al., 1996; Yasoshima et al., 2006). Lamprecht and Dudai (1995) demonstrated that the expression of c-fos mRNA is markedly increased in the CeA shortly after the systemic administration of the gastrointestinal toxin $\mathrm{LiCl}$ and, moreover, that this induction is needed for the acquisition of CTA memory (Lamprecht and Dudai, 1996). Several studies have also shown that c-Fos is significantly induced in the CeA (Spencer and Houpt, 2001; Bernstein and Koh, 2007) and in the BLA (Ferreira et al., 2006; St Andre et al., 2007) because of LiCl injection. This evidence suggests that changes in gene expression might be necessary for the proper amygdalar representation of the US, an important phase in CTA memory formation (Bernstein and Koh, 2007).

Importantly, Western blotting analyses also confirmed the amygdalar gene regulation of fen-1 at the protein level. Our results indicate that Fen-1 protein is significantly increased in the amygdala of CTA animals $3.5 \mathrm{~h}$ after training. In addition, we showed that this amygdalar increase of Fen-1 expression was not found in the insular cortex, another region involved in CTA consolidation (Gallo et al., 1992; Bermúdez-Rattoni and Yamamoto, 1998). Thus, our findings demonstrate that the amygdalar upregulation of Fen-1 after CTA is regionally specific, pointing perhaps to a particular involvement of the amygdala in consolidation processes that recruit DNA recombination/repair machineries. Interestingly, our previous studies (Colón-Cesario et al., 2006a) suggested similar differences between the hippocampus and cortical areas with respect to rapid induction of recombination/repair factors in response to conditioning. In addition, results from these previous studies suggested that hippocampal DNA recombination/repair mechanisms were activated in a dual wave manner, with an immediate and a more delayed response. These findings were reminiscent of previous findings with protein synthesis inhibitors in context fear conditioning (Bourtchouladze et al., 1998). Similar results were obtained with CTA (Houpt and Berlin, 1999). Our finding of Fen-1 induction at $3 \mathrm{~h}$ after CTA training may represent one of the waves of recombination/repair necessary for consolidation.

Because of the widely established role of Fen-1 during DNA replication (Liu et al., 2004), a process common for all type of cells, we wanted to determine the cellular localization of this endonuclease within the amygdala after CTA. Results from our immunofluorescence analysis demonstrated that NeuN, but not GFAP, was colocalized with Fen-1 expression, suggesting that Fen-1-positive cells are predominantly neurons. Indeed, the constitutive Fen-1 expression in rat neuronal cells is significantly 
a

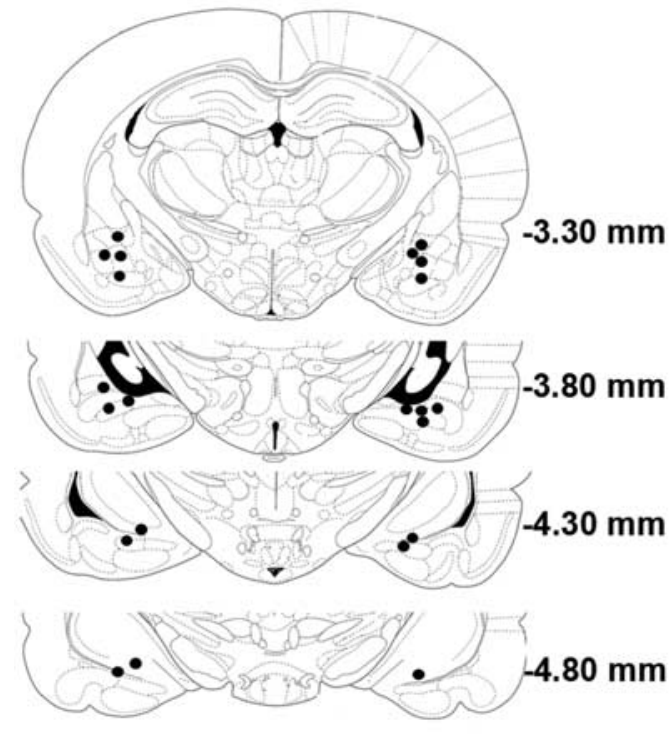

d

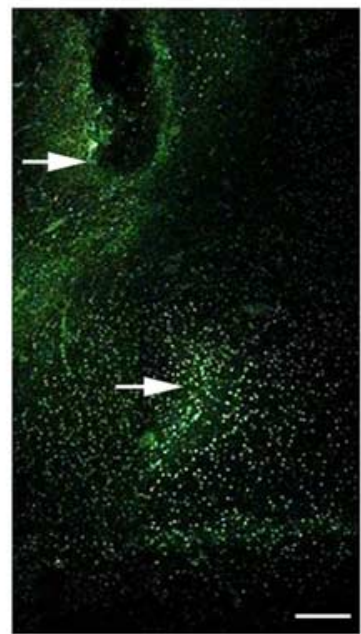

b

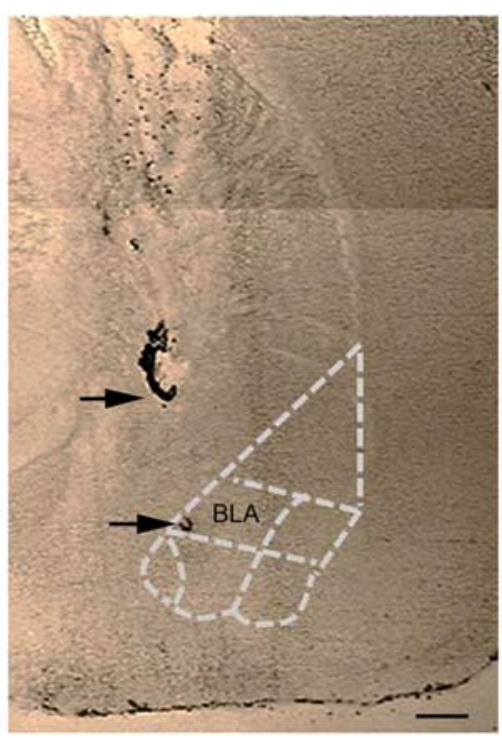

C

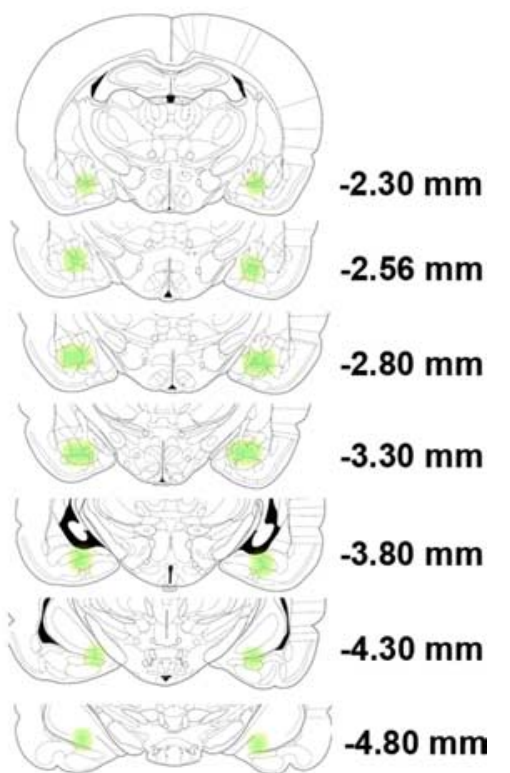

e

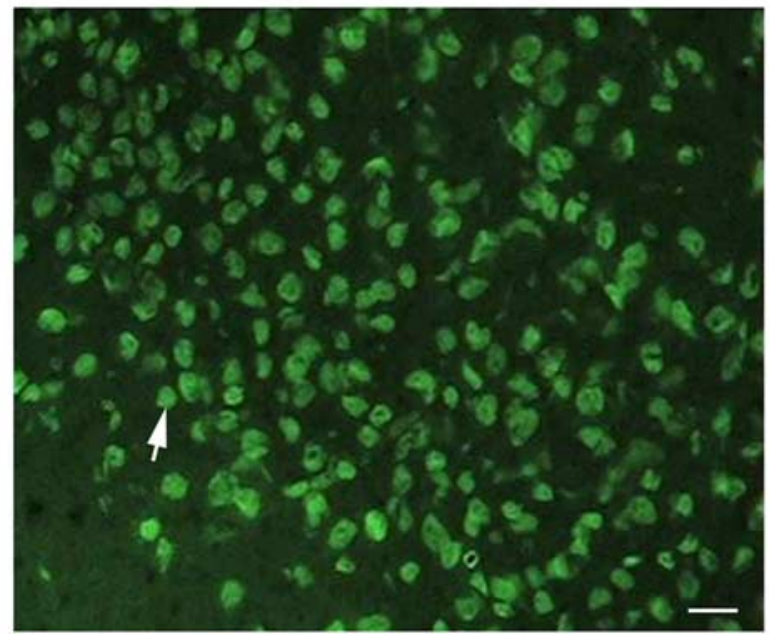

Figure 6. Cannula placements and fen-1 antisense oligonucleotide diffusion within the amygdala. $\boldsymbol{a}$, Schematic representation of the amygdala at different rostrocaudal planes illustrating cannulations. After behavioral treatments, fen- 1 antisense and random oligonucleotide-treated rats ( $n=11$ animals per treatment) were decapitated, their brains were dissected, and coronal sections were obtained to verify cannula placements. Injector tips for each cannula are represented by dark circles. Most tips targeted the BLA, the CeA, and the LaVM. A few tips were also found targeting more posterior amygdalar areas. The numbers indicate the distance from bregma in millimeters. $\boldsymbol{b}$, Representative bright light photomicrograph of a cannula track (top arrow) and injector tip (bottom arrow) targeting the BLA. Scale bar, $0.01 \mathrm{~mm}$ (1× magnification). c, Schemes of coronal sections showing the diffusion of microinjected FITC-fen-1 antisense oligonucleotides into the amygdala of animals $(n=4)$ decapitated $3 \mathrm{~h}$ after the last oligonucleotide infusion. The fluorescently labeled fen- 1 antisense (represented by green shading) was detected through different amygdalar nuclei from anterior to posterior areas, especially in the basolateral amygdalar complex. $\boldsymbol{d}$, Representative photomicrograph (corresponding to the same section as in $\boldsymbol{b}$ ) showing FITC-fen-1 antisense oligonucleotide diffusion in the BLA. The cannula track and the injector tip area are also visible and pointed out with arrows. Scale bar, $0.1 \mathrm{~mm}$ (10 $\times$ magnification). $\boldsymbol{e}$, Photomicrograph at higher magnification indicating the incorporation of the FITC-fen- 1 antisense oligonucleotides into the cells. Scale bar, $0.2 \mathrm{~mm}$ ( $20 \times$ magnification).

higher than the basal Fen-1 expression in astrocytes. Overall, the findings discussed so far suggest that Fen-1 amygdalar induction was behavioral, temporal, and regional-specific.

\section{Fen-1 is required for CTA memory consolidation}

As stated above, the amygdala is important for the generation of the representation of the US component of CTA and blocking the formation of such representation blocks CTA consolidation (Lamprecht and Dudai, 1996; Swank et al., 1996; Yasoshima et al., 2006). Hence, we decided to extend our studies by using experiments addressing the functional role of fen-1 in the formation of CTA memory. Antisense, but not random, oligonucleotides were effective in selectively suppressing the levels of amygdalar fen-1 mRNA, and also impaired CTA consolidation without affecting short-term memory or the future capacity to learn a novel CTA experience (Fig. 7). It is unlikely that these findings are attributable to interference of the CS representation, an argument that could be made based on our double-injection approach, because amygdalar fen-1 expression was unrelated to the flavor component of CTA, and no effect was found on the short-term memory test. More importantly, the findings of our fen-1 knockdown studies rule out 
a
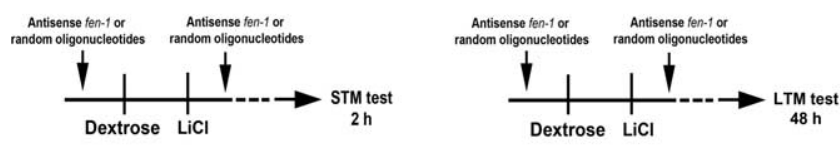

b

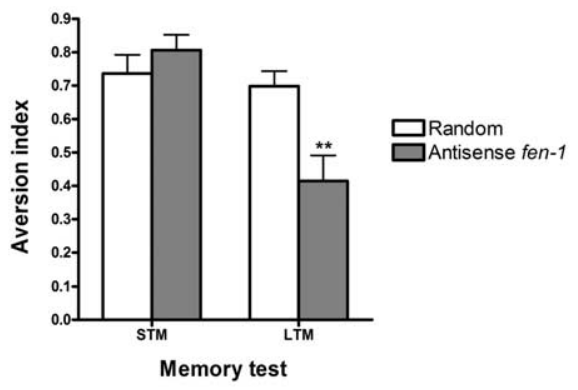

C

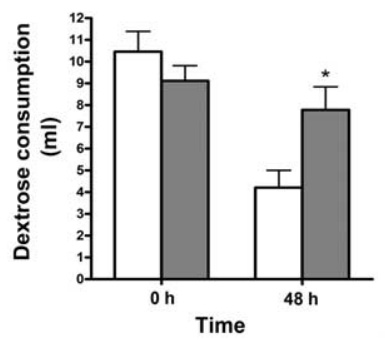

Figure 7. Amygdalar fen-1 antisense treatment caused impairment of (TA memory consolidation. $\boldsymbol{a}$, Left, Animals were infused into the amygdala with fen- 1 antisense $(n=6)$ or random $(n=6)$ oligonucleotides $1 \mathrm{~h}$ before the dextrose and $1 \mathrm{~h}$ after the $\mathrm{LiCl}$ injection, and STM was tested $2 \mathrm{~h}$ after conditioning. $\boldsymbol{a}$, Right, A separate group of rats were infused into the amygdala with fen- 1 antisense $(n=11)$ or random oligonucleotides $(n=11) 1 \mathrm{~h}$ before the dextrose and $1 \mathrm{~h}$ after the LiCl injection and subjected to a LTM test $48 \mathrm{~h}$ after conditioning. $\boldsymbol{b}$ Bar graph depicting the differences in aversion index between fen- 1 antisense and random oligonucleotide-treated rats, during the STM or LTM tests. The fen-1 antisense-treated rats (gray bars) had a significantly lower aversion to the dextrose than the random-treated animals (white bars), only during the LTM test $48 \mathrm{~h}$ after conditioning (Bonferroni's posttest, ${ }^{* *} p<$ 0.01). c, Bar graphs showing the differences in dextrose consumption (in milliliters) between fen- 1 antisense (gray graphs) and random (white bars) oligonucleotide-treated animals at the time of $(S$ presentation (time 0 ) and the LTM test ( $48 \mathrm{~h}$ after training). Two-way ANOVA detected significant differences in dextrose consumption between the groups only during the memory test (Bonferroni's posttesting, ${ }^{*} p<0.05$ ). These results suggest that the antisense treatment did not make the animals sick, since both groups ingested similar volumes of dextrose at the initial CS presentation. In addition, the fen- 1 antisense-treated rats consumed more dextrose than controls at $48 \mathrm{~h}$, indicating that they had poorer memory of the taste-illness association. Error bars indicate SEM.

the possibility that Fen-1 function is solely related to the illness experience and support the notion that this DNA endonuclease is required for associative memory formation.

Mechanisms of action of Fen-1 in DNA recombination/repair This report constitutes the first to demonstrate that Fen-1, and for that matter any DNA endonuclease, is a factor involved in memory processes in the brain. Fen-1 is a structure-specific nuclease with three different activities, including $5^{\prime}$-flap endonuclease, $5^{\prime}$-exonuclease, and gap endonuclease activities (Liu et al., 2004; Shen et al., 2005). These functions are critical for Okazaki fragment processing during DNA replication, for DNA repair, and recombination (Liu et al., 2004). In the case of DNA repair, Fen-1 participates in the long patch base excision pathway, recognizing the abasic sites left by the apurinic/apyrimidinic endonuclease cleavage (Ranalli et al., 2002). Fen-1 also participates during NHEJ, an intermediary repair phase within variable-di- versity-joining region $[\mathrm{V}(\mathrm{D}) \mathrm{J}]$ recombination of the immune system, by processing the DNA flaps that occur after DNA end alignments (Wu et al., 1999). In addition to the roles in DNA replication and repair, Fen-1 has been involved in the maintaining of genomic stability and preventing the expansion of repeat sequences (Liu et al., 2004).

The impairment caused by amygdalar Fen- 1 suppression on CTA consolidation seems to be more related to a possible blockade of DNA recombination/repair functions, involving Fen-1, than to an interruption of DNA replication. There are no conclusive findings supporting that cell proliferation and DNA synthesis are activated in the amygdala after a single-trial conditioning task, such as CTA. In addition, controversial data exist regarding neurogenesis in the amygdala (Bernier et al., 2002; Park et al., 2006; Gould, 2007; Fowler et al., 2008). In all the cases identifying new cells in the amygdala, it is unclear whether such new cells were generated in situ or whether they were generated in the subventricular zone (SVZ) and then migrated into the amygdala, a more likely scenario than the former. Moreover, newborn cells of highly neurogenic regions, such as the SVZ and the hippocampus, are still immature $48 \mathrm{~h}$ after DNA synthesis and require between 4 and 5 weeks to become incorporated into functional circuitries (van Praag et al., 2002). These temporal boundaries depart from those seen here both for upregulation of fen-1 expression after CTA and for the expression of amnesic effects caused by fen- 1 knockdown evident $48 \mathrm{~h}$ after acquisition. As indicated above, LTM formation is known to require transcriptional regulation of gene expression (Kida et al., 2002). In fact, facilitation of transcription by chromatin relaxation as a result of the regulation of histone acetylation is also important for LTM (Levenson and Sweatt, 2005; Vecsey et al., 2007). We propose that DNA recombination/repair mechanisms involving Fen-1, DNA ligase, and TdT, possibly operate upstream of transcriptional regulation as occurs with $\mathrm{V}(\mathrm{D}) \mathrm{J}$ recombination in the immune system (Schatz, 2004). It is also possible that DNA recombination/ repair mechanisms may affect transcription by altering the promoter region of specific target genes so that may be transcribed constitutively after a learning experience that will lead to the formation of a durable memory.

\section{Conclusion}

These studies have helped identify a novel factor required for the consolidation of aversive memories. Because of the known and well characterized biochemical functions of Fen-1 as a DNA endonuclease, our findings provide support for the proposed role of DNA recombination/repair mechanisms in memory consolidation (Peña de Ortiz and Arshavsky, 2001; Peña de Ortiz et al., 2003; Wang et al., 2003; Colón-Cesario et al., 2006a). Studies by other groups also support the notion that the immune and nervous systems might share similar mechanisms to establish or strengthen synaptic connections (Huh et al., 2000; Boulanger et al., 2001; Syken and Shatz, 2003). Future work will help elucidate in more detail the specific molecular mechanisms mediated by Fen-1 during the memory consolidation processes for aversive experiences.

\section{References}

Alberini CM, Ghirardi M, Metz R, Kandel ER (1994) C/EBP is an immediate-early gene required for the consolidation of long-term facilitation in Aplysia. Cell 76:1099-1114.

Bassing CH, Swat W, Alt FW (2002) The mechanism and regulation of chromosomal V(D)J recombination. Cell 109:45-55.

Benedict CL, Gilfillan S, Thai TH, Kearney JF (2000) Terminal deoxynu- 
cleotidyl transferase and repertoire development. Immunol Rev 175:150-157.

Bermúdez-Rattoni F (2004) Molecular mechanisms of taste recognition memory. Nat Rev Neurosci 5:209-217.

Bermúdez-Rattoni F, McGaugh JL (1991) Insular cortex and amygdala lesions differentially affect acquisition on inhibitory avoidance and conditioned taste aversion. Brain Res 549:165-170.

Bermúdez-Rattoni F, Yamamoto T (1998) Neuroanatomy of conditioned taste aversion: lesion studies. In: Conditioned taste aversion (Bures J, Bermúdez-Rattoni F, Yamamoto T, eds), pp 26-45. Oxford: Oxford UP.

Bernier PJ, Bedard A, Vinet J, Levesque M, Parent A (2002) Newly generated neurons in the amygdala and adjoining cortex of adult primates. Proc Natl Acad Sci U S A 99:11464-11469.

Bernstein IL (1999) Taste aversion learning: a contemporary perspective. Nutrition 15:229-234.

Bernstein IL, Koh MT (2007) Molecular signaling during taste aversion learning. Chem Senses 32:99-103.

Boulanger LM, Huh GS, Shatz CJ (2001) Neuronal plasticity and cellular immunity: shared molecular mechanisms. Curr Opin Neurobiol 11:568-578.

Bourtchouladze R, Abel T, Berman N, Gordon R, Lapidus K, Kandel ER (1998) Different training procedures recruit either one or two critical periods for contextual memory consolidation, each of which requires protein synthesis and PKA. Learn Mem 5:365-374.

Bures J (1998) Ethology, physiological psychology, and neurobiology of CTA. In: Conditioned taste aversion (Bures J, Bermúdez-Rattoni F, Yamamoto T, eds), pp 1-10. Oxford: Oxford UP.

Casta LJ, Buguliskis JS, Matsumoto Y, Taraschi TF (2008) Expression and biochemical characterization of the Plasmodium falciparum DNA repair enzyme, flap endonuclease-1 (PfFEN-1). Mol Biochem Parasitol $157: 1-12$.

Colón-Cesario M, Wang J, Ramos X, García HG, Dávila JJ, Laguna J, Rosado C, Peña de Ortiz S (2006a) An inhibitor of DNA recombination blocks memory consolidation, but not reconsolidation, in context fear conditioning. J Neurosci 26:5524-5533.

Colón-Cesario WI, Martínez-Montemayor MM, Morales S, Félix J, Cruz J, Adorno M, Pereira L, Colón N, Maldonado-Vlaar CS, Peña de Ortiz S (2006b) Knockdown of Nurr1 in the rat hippocampus: implications to spatial discrimination learning and memory. Learn Mem 13:734-744.

Crick F (1984) Memory and molecular turnover. Nature 312:101.

Ferreira G, Ferry B, Meurisse M, Lévy F (2006) Forebrain structures specifically activated by conditioned taste aversion. Behav Neurosci 120:952-962.

Fowler CD, Liu Y, Wang Z (2008) Estrogen and adult neurogenesis in the amygdala and hypothalamus. Brain Res Rev 57:342-351.

Gallo M, Roldan G, Bures J (1992) Differential involvement of gustatory insular cortex and amygdala in the acquisition and retrieval of conditioned taste aversion in rats. Behav Brain Res 52:91-97.

Garcia J, Lasiter PS, Bermúdez-Rattoni F, Deems DA (1985) A general theory of aversion learning. Ann N Y Acad Sci 443:8-21.

Ge H, Chiesa R, Peña de Ortiz S (2003) HZF-3 expression in the amygdala after establishment of conditioned taste aversion. Neuroscience 1:1-4.

Gellert M (2002) V(D)J recombination: RAG proteins, repair factors, and regulation. Annu Rev Biochem 71:101-132.

Gould E (2007) How widespread is adult neurogenesis in mammals? Nat Rev Neurosci 8:481-488.

Gu Y, Gonzalez MF, Chin DY, Deutsch JA (1993) Expression of c-fos in brain subcortical structures in response to nauseant lithium chloride and osmotic pressure in rats. Neurosci Lett 157:49-52.

Houpt TA, Berlin R (1999) Rapid, labile, and protein synthesisindependent short-term memory in conditioned taste aversion. Learn Mem 6:37-46.

Huh GS, Boulanger LM, Du H, Riquelme PA, Brotz TM, Shatz CJ (2000) Functional requirement for class I MHC in CNS development and plasticity. Science 290:2155-2159.

Kida S, Josselyn SA, de Ortiz SP, Kogan JH, Chevere I, Masushige S, Silva AJ (2002) CREB required for the stability of new and reactivated fear memories. Nat Neurosci 5:348-355.

Korzus E, Rosenfeld MG, Mayford M (2004) CBP histone acetyltransferase activity is a critical component of memory consolidation. Neuron 42:961-972.
Lamprecht R, Dudai Y (1995) Differential modulation of brain immediate early genes by intraperitoneal LiCl. Neuroreport 7:289-293.

Lamprecht R, Dudai Y (1996) Transient expression of c-fos in rat amygdala during training is required for encoding conditioned taste aversion memory. Learn Mem 3:31-41.

Lamprecht R, Dudai Y (2000) The amygdala in conditioned taste aversion: it's there but where? In: The amygdala (Aggleton J, ed), pp 310-331. New York: Oxford UP.

Levenson JM, Sweatt JD (2005) Epigenetic mechanisms in memory formation. Nat Rev Neurosci 6:108-118.

Liu Y, Kao HI, Bambara RA (2004) Flap endonuclease 1: a central component of DNA metabolism. Annu Rev Biochem 73:589-615.

Morris R, Frey S, Kasambira T, Petrides M (1999) Ibotenic acid lesions of the basolateral, but not the central, amygdala interfere with conditioned taste aversion: evidence from a combined behavioral and anatomical tract-tracing investigation. Behav Neurosci 113:291-302.

Park JH, Cho H, Kim H, Kim K (2006) Repeated brief epileptic seizures by pentylenetetrazole cause neurodegeneration and promote neurogenesis in discrete brain regions of freely moving adult rats. Neuroscience 140:673-684.

Pavlov YI, Shcherbakova PV, Rogozin IB (2006) Roles of DNA polymerases in replication, repair, and recombination in eukaryotes. Int Rev Cytol 255:41-132.

Paxinos G, Watson C (1998) The rat brain in stereotaxic coordinates, Ed 4. New York: Academic.

Peña de Ortiz S, Arshavsky Y (2001) DNA recombination as a possible mechanism in declarative memory: a hypothesis. J Neurosci Res 63:72-81.

Peña de Ortiz S, Maldonado-Vlaar CS, Carrasquillo Y (2000) Hippocampal expression of the orphan nuclear receptor gene $h z f-3 /$ nurrl during spatial discrimination learning. Neurobiol Learn Mem 74:161-178.

Peña de Ortiz S, Colón M, Carrasquillo Y, Padilla B, Arshavsky YI (2003) Experience-dependent expression of terminal deoxynucleotidyl transferase in mouse brain. Neuroreport 14:1141-1144.

Quevedo J, Vianna MR, Martins MR, Barichello T, Medina JH, Roesler R, Izquierdo I (2004) Protein synthesis, PKA, and MAP kinase are differentially involved in short- and long-term memory in rats. Behav Brain Res 154:339-343.

Ranalli TA, Tom S, Bambara RA (2002) AP endonuclease 1 coordinates flap endonuclease 1 and DNA ligase I activity in long patch base excision repair. J Biol Chem 277:41715-41724.

Ren K, Peña de Ortiz S (2002) Non-homologous DNA end joining in the mature rat brain. J Neurochem 80:949-959.

Robles Y, Vivas-Mejía PE, Ortiz-Zuazaga HG, Félix J, Ramos X, Peña de Ortiz S (2003) Hippocampal gene expression profiling in spatial discrimination learning. Neurobiol Learn Mem 1:80-95.

Rollins BL, Stines SG, McGuire HB, King BM (2001) Effects of amygdala lesions on body weight, conditioned taste aversion, and neophobia. Physiol Behav 72:735-742.

Schafe GE, LeDoux JE (2000) Memory consolidation of auditory pavlovian fear conditioning requires protein synthesis and protein kinase $\mathrm{A}$ in the amygdala. J Neurosci 20:RC96(1-5).

Schafe GE, Thiele TE, Bernstein IL (1998) Conditioning method dramatically alters the role of amygdala in taste aversion learning. Learn Mem 5:481-492.

Scharf MT, Woo NH, Lattal KM, Young JZ, Nguyen PV, Abel T (2002) Protein synthesis is required for the enhancement of long-term potentiation and long-term memory by spaced training. J Neurophysiol 87:2770-2777.

Schatz DG (2004) Antigen receptor genes and the evolution of a recombinase. Semin Immunol 16:245-256.

Shen B, Singh P, Liu R, Qiu J, Zheng L, Finger LD, Alas S (2005) Multiple but dissectible functions of FEN-1 nucleases in nucleic acid processing, genome stability and diseases. Bioessays 27:717-729.

Silva AJ, Kogan JH, Frankland PW, Kida S (1998) CREB and memory. Annu Rev Neurosci 21:127-148.

Soulas-Sprauel P, Rivera-Munoz P, Malivert L, Le Guyader G, Abramowski V, Revy P, de Villartay JP (2007) V(D)J and immunoglobulin class switch recombinations: a paradigm to study the regulation of DNA-end joining. Oncogene 26:7780-7791.

Spencer CM, Houpt TA (2001) Dynamics of c-fos and ICER mRNA expres- 
sion in rat forebrain following lithium chloride injection. Mol Brain Res 93:113-126.

Squire LR, Barondes SH (1970) Actinomycin-D: effects on memory at different times after training. Nature 225:49-50.

St Andre J, Albanos K, Reilly S (2007) c-fos expression in the rat brain following lithium chloride-induced illness. Brain Res 1135:122-128.

Swank MW, Ellis AE, Cochran BN (1996) c-fos antisense blocks acquisition and extinction of conditioned taste aversion in mice. Neuroreport 7:1866-1870.

Syken J, Shatz CJ (2003) Expression of T cell receptor beta locus in central nervous system neurons. Proc Natl Acad Sci U S A 100:13048-13053.

van Praag H, Schinder AF, Christie BR, Toni N, Palmer TD, Gage FH (2002) Functional neurogenesis in the adult hippocampus. Nature 415:1030-1034.

Vázquez A, Peña de Ortiz S (2004) Lead $(\mathrm{Pb}(+2))$ impairs long-term memory and blocks learning-induced increases in hippocampal protein kinase C activity. Toxicol Appl Pharmacol 200:27-39.

Vecsey CG, Hawk JD, Lattal KM, Stein JM, Fabian SA, Attner MA, Cabrera SM, McDonough CB, Brindle PK, Abel T, Wood MA (2007) Histone deacetylase inhibitors enhance memory and synaptic plasticity via CREB: CBP-dependent transcriptional activation. J Neurosci 27:6128-6140.

Wang J, Ren K, Pérez J, Silva AJ, Peña de Ortiz S (2003) The antimetabolite
ara-CTP blocks long-term memory of conditioned taste aversion. Learn Mem 10:503-509.

Wu X, Wilson TE, Lieber MR (1999) A role for FEN-1 in nonhomologous DNA end joining: the order of strand annealing and nucleolytic processing events. Proc Natl Acad Sci U S A 96:1303-1308.

Yamamoto T (2006) Neural substrates for the processing of cognitive and affective aspects of taste in the brain. Arch Histol Cytol 69:243-255.

Yamamoto T, Shimura T, Sako N, Azuma S, Bai WZ, Wakisaka S (1992) c-fos expression in the rat brain after intraperitoneal injection of lithium chloride. Neuroreport 3:1049-1052.

Yamamoto T, Sako N, Sakai N, Iwafune A (1997) Gustatory and visceral inputs to the amygdala of the rat: conditioned taste aversion and induction of c-fos-like immunoreactivity. Neurosci Lett 226:127-130.

Yasoshima Y, Sako N, Senba E, Yamamoto T (2006) Acute suppression, but not chronic genetic deficiency, of c-fos gene expression impairs long-term memory in aversive taste learning. Proc Natl Acad Sci U S A 103:7106-7111.

Zhang R, Lu Z, Zhao H, Zhang X, Diasio R, Habus I, Jiang Z, Iyer R, Yu D, Agrawal S (1995) In vivo stability, disposition, and metabolism of a "hybrid" oligonucleotide phosphorothioate in rats. Biochem Pharmacol 50: 545-556. 